\title{
Chemical speciation of lead adsorbed onto volcanic ashes by ICP-OES and XANES
}

\author{
B. Blixen ${ }^{a}$, B. Thiodjio ${ }^{b}$, N. Medellin ${ }^{c, *}$, R. Loredo ${ }^{d}$, G. Labrada $^{e}$, \\ C. Carranza ${ }^{f}$, B. Germain ${ }^{a}$, R. Leyva ${ }^{g}$, and S. Reyes ${ }^{h}$ \\ ${ }^{a}$ University of Yaounde I, Faculty of Sciences, Yaounde, Cameroon. \\ ${ }^{b}$ University of Yaounde I, National Advanced School of Engineering of Yaounde, Yaounde, Cameroon. \\ ${ }^{c}$ Autonomous University of San Luis Potosi, Faculty of Engineering, San Luis Potosi, S.L.P., Mexico. \\ e-mail: nahum.medellin@uaslp.mx. \\ ${ }^{d}$ CONACyT-National Autonomous University of Mexico, Geology Institute, \\ Regional Northwest Station, Hermosillo, Sonora, Mexico. \\ ${ }^{e}$ Instituto Potosino de Investigacion Cientifica y Tecnologica, A.C., San Luis Potosi, S.L.P., Mexico. \\ ${ }^{f}$ Autonomous University of San Luis Potosi-Unidad Académica Multidisciplinaria Zona Huasteca, \\ Cd. Valles, S.L.P., Mexico. \\ ${ }^{g}$ Autonomous University of San Luis Potosi, Faculty of Chemical Sciences, San Luis Potosi, S.L.P., Mexico. \\ ${ }^{h}$ Autonomous University of Ciudad Juarez, Juarez City, Chihuahua, Mexico.
}

Received 20 September 2021; accepted 21 November 2021

\begin{abstract}
In this work, the potential of Volcanic Ashes (VA) from the Cameroon Volcanic Line (CVL) as adsorbents of Pb(II) from aqueous solutions was studied. The chemical speciation of lead adsorbed onto volcanic ashes based by means of inductively coupled plasma optical emission spectroscopy (ICP-OES) and X-ray absorption near edge spectroscopy (XANES) study is reported. The experiments were done using the ashes from CVL to remove lead in aqueous solutions. The maximum value of the adsorption capacity of lead in VA was determined to be $7.60 \mathrm{mg} \mathrm{g}^{-1}$ at $\mathrm{pH}$ 5. Regarding the adsorption process, the contribution of the mixture $\mathrm{Pb}$ components after adsorption and a strong interaction of adsorbed $\mathrm{Pb}$ with the surface of volcanic ashes were proven. The chemical elements present in the VA and their concentrations are determined by ICP-OES. Chemical speciation was carried out measuring Pb saturated VA sample at the L3 edge (13035 eV) at the XAFS beam line in Elettra Sincrotrone (Trieste). The XANES measurements showed that the $\mathrm{Pb}$ removal occurred mainly by microprecipitation of lead acetate and carbonate associated with a possible ion-exchange forming lead monoxide.
\end{abstract}

Keywords: X-ray absorption spectroscopy; volcanic ashes; microprecipitation; ion exchange.

DOI: https://doi.org/10.31349/SuplRevMexFis.3.010602

\section{Introduction}

In general, the lands around volcanoes are frequently subjected to the intermittent flow of lava and deposition of volcanic ash (VA) during the volcano's eruption. Monthly smallscale explosive volcanic eruptions can emit more than a million cubic meters of ashes into Earth's atmosphere [1]. As soon as these ejections from volcanic eruptions are deposited onto the surrounding soils, the soil formation process starts, which produces a modification in its mineralogical composition leading the volcanic soils to have some specific properties such as water holding capacity low bulk density.

The fertile volcanic soils found in Cameroon result from the chemical weathering of volcanic rocks ejected from Mount Cameroon volcano. They possess various properties useful in diverse applications, including agriculture, construction, and wastewater treatment. Mount Cameroon is the unique active volcano along the CVL and is an important regional feature in West-Central Africa. The analysis of eruption lava showed a variation in its chemical composition up to the normal level standard of good quality of soils [2]. Despite of these results, few chemical speciation studies were carried out to contribute to the improvement for keeping safety the environment and soils of the involved localities. In addition, these authors were interested in the quality status of the neighboring soils of the Mount Cameroon volcano by identifying trace elements [2]. The results showed that water is acidic and that some metals such as $\mathrm{Cr}, \mathrm{Zn}, \mathrm{Ni}$, and $\mathrm{Pb}$ have elevated concentrations resulting from the volcanic eruption. These volcanic soils are acidic and are mainly dedicated to the agricultural and water purification sectors. The physical, mechanical, and reactivity properties of VAs based on geopolymer mortars have also been evaluated [2,3]. VA from Cameroon then proved being effective for cement manufacturing and in the agricultural sector. However, these have not been tested as an adsorbent to remove contaminants in an aqueous solution. For instance, few works were dedicated to studying their use as material for the removal of arsenic (As), zinc $(\mathrm{Zn})$, lead $(\mathrm{Pb})$, and phosphorous $(\mathrm{P})$ from aqueous solution using VA from Puyehue-(Chile), Kerman-(Iran) and Ibaraki-(Japan) [5-7]. In addition, the inhalation and ingestion of some toxic elements such as chromium $(\mathrm{Cr})$, cadmium $(\mathrm{Cd})$, nickel $(\mathrm{Ni})$, iron $(\mathrm{Fe}), \mathrm{Zn}$, and $\mathrm{Pb}$ are harmful to human or animal health when they are chronically exposed since they can cause severe damages leading to dangerous diseases such as circulatory disorders, chronic bronchitis, dental and 
skeletal fluorosis [8]. These elements could be removed from water using VA as adsorbent material at the same level as any other adsorbent, such as the low-cost synthetic minerals [9], smectite, and kaolinite [10].

It should be noted that the removal of $\mathrm{Pb}$ in aqueous solutions with such VA materials is not well documented, even though its recommended concentration is $0.1 \mathrm{mg} \mathrm{L}^{-1}$ for drinking water [11]. Nonetheless, the removal of $\mathrm{Pb}^{2+}$ onto silicon-rich biochars was investigated by [12] using techniques such as X-ray Absorption near edge spectroscopy (XANES) and extended X-ray absorption fine structure (EXAFS), among others. They found that the $\mathrm{K}, \mathrm{Ca}, \mathrm{Cu}, \mathrm{Mn}$, and $\mathrm{Fe}$ elements were significantly related to $\mathrm{Pb}$ and were released in the samples. In addition, they showed that $\mathrm{Pb}_{3}\left(\mathrm{PO}_{4}\right)_{2}, \mathrm{PbSiO}_{3}$, and $\mathrm{PbCO}_{3}$ species were formed with similar structures to lead carboxylate.

This study focuses on the assessment of the VA materials from the Moungo zone (Fig. 1) of the Cameroon volcanic line (CVL) between the mount Cameroon volcano and Mount Koupé, for their use as natural adsorbents to remove $\mathrm{Pb}^{2+}$ pollutant from aqueous solutions. Fourier transform infrared (FTIR), inductively coupled plasma optical emission spectroscopy (ICP-OES), and X-ray absorption near edge structure (XANES) techniques are used to characterize the studied VA. These techniques were used in some studies to assess the whole properties of the adsorbed VA [5,6]. XANES was also utilized to probe the electronic and structural properties of a specific element in various compounds $[12,13]$.

\section{Materials and methods}

The raw materials VA samples were collected in the Moungo zone inside the CVL in the center of the CIMENCAM quarry at sites 1 and 2, as indicated in Fig. 1. The details on the collected samples labelled P1, P2 and P3 are given in Table I. All collected samples were air dried for $24 \mathrm{~h}$.

The adsorption tests were done using the methodology described in [14]. An unsaturated solution of $100 \mathrm{mg} \mathrm{L}^{-1}$ of $\mathrm{Pb}^{2+}$ solution was prepared from $\mathrm{Pb}\left(\mathrm{NO}_{3}\right)_{2}$ reagent grade (solubility in water $597 \mathrm{~g} \mathrm{~L}^{-1}$ ) and deionized water. Then, 10 $\mathrm{mL}$ of the solution was collected to analyze the initial concentration, and then $40 \mathrm{~mL}$ of the same solution was mixed with $0.2 \mathrm{~g}$ of sample P1; the final concentration was measured at the end of the experiment. The $\mathrm{pH}$ of the mixture was adjusted at three values: 3,4 , and 5, respectively. The suspensions were left for 7 days to reach the equilibrium state, and their $\mathrm{pH}$ was adjusted daily. The raw sample and $\mathrm{Pb}^{2+}$ adsorbed sample were respectively named UVA (unsaturated $\mathrm{VA}$ ) and $\mathrm{Pb}-\mathrm{SVA}\left(\mathrm{Pb}\right.$ saturated VA). The $\mathrm{Pb}^{2+}$ initial and final concentrations were measured using flame atomic absorption spectroscopy (FAAS). The Atomic absorption spectrometer (Varian 220) was operated under the current of $5 \mathrm{~mA}$ at the wavelength of $261.4 \mathrm{~nm}$ with $0.5 \mathrm{~nm}$ slit width.

The ICP-OES measurements were performed by dissolving with concentrated $\mathrm{HNO}_{3}$ and $\mathrm{HCl}$ the VA powder in a proportion of $0.1 \mathrm{~g}$ of $\mathrm{VA}$ in $10 \mathrm{~mL}(1: 100 \mathrm{w} / \mathrm{v})$ [15]. The equipment used was an ICP-OES brand Varian model 738 ES with the torch placed at the axial position and nebulizer flow of $0.75 \mathrm{~L} \mathrm{~min}^{-1}$. All samples were analyzed in triplicate, having a relative standard deviation $<2.0$ and with a limit of the detection of the apparatus below $0.01 \mathrm{mg} \mathrm{kg}^{-1}$. The results of the average concentration of the elements in the VA samples are reported in Table II. Infrared (IR) analysis of the VA was performed on a Thermo Scientific Nicolet iS10 FTIR spectrophotometer. The analysis comprised 32 cycles in a range from 520 to $4000 \mathrm{~cm}^{-1}$. The VA samples were mixed with $\mathrm{KBr}$ in a 1:300 ratio. A toxicity characteristic leaching procedure was designed to determine the mobility of different inorganic analytes present in solid waste (VA). This procedure was according to US EPA international method 1311 [16].

To perform XANES measurements, the pellets for VA samples were prepared by mixing $100 \mathrm{mg}$ of the saturated $\mathrm{Pb}$ SVA-P1 with $50 \mathrm{mg}$ of polyvinylpyrrolidone. XANES measurements of Pb-SVA-P1 were done in fluorescence mode at the $\mathrm{L} 3$ edge of $\mathrm{Pb}$, at the XAFS beamline [17] of Elettra Synchrotron (Trieste, Italy). The storage ring was operated at $2 \mathrm{GeV}$ yielding a current of $310 \mathrm{~mA}$. The first inflection point of the L3-edge XANES spectrum of $\mathrm{Pb}$ was assigned to $13,035 \mathrm{eV}$ to calibrate a double crystal silicon $\mathrm{Si}$ (111) monochromator. The x-ray absorption data were collected in the energy range of [12,735.00-13,781.75] eV and the wave vector range of $[0-14] \AA^{-1}$. All spectra collected for each sample were averaged and then normalized to one absorption spectra using ATHENA software [18]. Principal component analysis (PCA) and Target Transform (TT) were used in ATHENA [18] to determine the number and types of the standards useful of a linear combination fitting (LCF). LCF was performed in an energy range of $-20 \mathrm{eV}$ below to $+30 \mathrm{eV}$ above the edge using at least 4 model compounds according to PCA. The lead compounds, $\mathrm{PbS}, \mathrm{PbO}, \mathrm{PbO}_{2}$, $\mathrm{Pb}_{2} \mathrm{O}_{4}, \mathrm{~Pb}\left(\mathrm{CO}_{3}\right), \mathrm{Pb}\left(\mathrm{SO}_{4}\right), \mathrm{Pb}\left(\mathrm{C}_{2} \mathrm{H}_{3} \mathrm{O}_{2}\right)_{2}$, and $\mathrm{Pb}$-sorbed onto Goethite $(\mathrm{Pb}-\alpha-\mathrm{FeOOH})$ were utilized as standards for the fitting. The XANES spectra of all compounds were compared to the spectra of VA samples to check the oxidation state and guess the suitable standards. The $R_{\text {factor }}$ indicates the most likely combination resulting in the best fit, which guides the choice of the good components possible present in the sample.

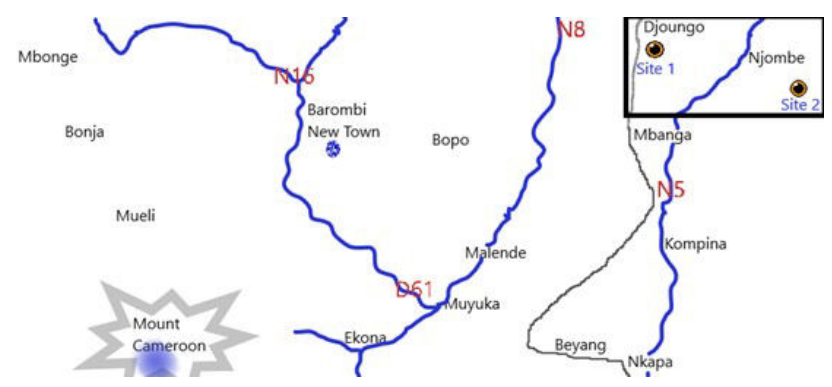

FIGURE 1. Map showing the location of sampling points. The black rectangle indicates the area where the samples were collected. 
TABLE I. Description of the VA and the geographic location.

\begin{tabular}{ccc|ccc}
\hline Samples & Description & Colour & \multicolumn{3}{c}{ Geographic coordinates } \\
\hline & North & East & Altitude & & \\
\hline P1 & Big scoops particles & Gray & $04^{\circ} 35^{\prime} 09^{\prime \prime}$ & $09^{\circ} 37^{\prime} 37^{\prime \prime}$ & $134 \pm 3 \mathrm{~m}$ \\
P2 & Average particles & Gray & $04^{\circ} 35^{\prime} 12^{\prime \prime}$ & $09^{\circ} 37^{\prime} 37^{\prime \prime}$ & $140 \pm 3 \mathrm{~m}$ \\
P3 & Small particles & Brown & $04^{\circ} 35^{\prime} 33^{\prime \prime}$ & $09^{\circ} 37^{\prime} 32^{\prime \prime}$ & $147 \pm 3 \mathrm{~m}$ \\
\hline
\end{tabular}

TABLE II. Concentration of trace elements in $\mathrm{mg} \mathrm{Kg}^{-} 1$ in volcanic ashes for all samples obtained from ICP-OES measurements. The values correspond to the average concentration. Relative standard deviation $<2.0 \%$.

\begin{tabular}{cccccccc}
\hline Elements & $\mathbf{P 1}$ & $\mathbf{P 2}$ & $\mathbf{P 3}$ & Elements & P1 & P2 & P3 \\
\hline $\mathbf{A l}$ & 5,739 & 98,782 & 74,825 & $\mathrm{Mg}$ & 6,883 & 41,975 & 43,995 \\
$\mathbf{B}$ & 29 & 21 & 25 & $\mathrm{Mn}$ & 789 & 1,719 & 1,649 \\
$\mathbf{B a}$ & 188 & 58 & 163 & $\mathrm{Na}$ & 8,186 & 22,307 & 19,235 \\
$\mathbf{C a}$ & 15,115 & 75,174 & 63,828 & $\mathrm{Ni}$ & 76 & 58 & 98 \\
$\mathbf{C d}$ & 6 & 2 & 5 & $\mathrm{P}$ & 1,013 & 511 & 985 \\
$\mathbf{C o}$ & 2 & 5 & 5 & $\mathrm{~Pb}$ & 14 & 7 & 13 \\
$\mathbf{C r}$ & 67 & 16 & 67 & $\mathrm{~S}$ & 127 & 27 & 1,593 \\
$\mathbf{C u}$ & 11 & 106 & 100 & $\mathrm{Si}$ & 48,646 & 439,644 & 45,3749 \\
$\mathbf{F e}$ & 23,327 & 103,048 & 100,199 & $\mathrm{Sr}$ & 238 & 95 & 223 \\
$\mathbf{K}$ & 5,356 & 12,584 & 10,442 & $\mathrm{Ti}$ & 1,901 & 18,978 & 17,797 \\
$\mathbf{Z n}$ & 66 & 25 & 59 & $\mathrm{~V}$ & 127 & 259 & 249 \\
\hline
\end{tabular}

\section{Results and discussion}

\subsection{Chemical speciation and functional groups}

The use of VA for further applications prior requires the chemical characterization to understand the whole properties related to their composition. The concentration of all elements in the volcanic ash samples obtained from ICP-OES is presented in Table II. The pollutants like Ag, As, Mo, Sb, Se, and $\mathrm{Ti}$ and light elements like $\mathrm{Be}$ and $\mathrm{Li}$ were not detected. In samples P1, P2, and P3, the first and second dominant elements are $\mathrm{Si}$ and $\mathrm{Fe}$, respectively, followed by $\mathrm{Al}$ and $\mathrm{Ca}$. The soil nutrients like $\mathrm{K}$ and $\mathrm{P}$ are also found with a significant concentration in all samples. The transition metals such as $\mathrm{Cd}, \mathrm{Cu}, \mathrm{Co}, \mathrm{Ni}, \mathrm{Pb}$, and $\mathrm{Zn}$ are present with low concentrations contrary to $\mathrm{Mn}$ and $\mathrm{Mg}$, whose concentrations are significant. As well, the presence of $\mathrm{S}$ is also noticed. Elevated concentrations of $\mathrm{Cr}, \mathrm{Ni}$, and $\mathrm{V}$ found in some rocks samples from Mount Cameroon can be due to the basaltic composition of parent rocks since basalts are enriched in Fe-family elements (Ti, V, Co, Ni, Cr) [2,19] . During the soil formation, the loss of some major elements favors these Fe-family elements, and they can also be affected by the soil age [20].

In general, the values of the above elements obtained in this study are higher than those in [21] from the normal landfill soils in Buea (Cameroon). It was proven that $\mathrm{Cd}, \mathrm{Cu}, \mathrm{Ni}$, $\mathrm{Pb}$, and $\mathrm{Zn}$ can adversely affect the growth of root grass in concentrations in the range of 40 to $50 \mathrm{mg} \mathrm{Kg}^{-1}$, while on the contrary, lower concentrations in the range of 5 to $20 \mathrm{mg}$ $\mathrm{Kg}^{-1}$ can stimulate the growth of the shoots [22]. Since our VA samples are product of the eruption of CVL of Mount Cameroon volcano, the high concentration values of these metals can be understood because of their origin. Manga $e t$ al. [2] found a similarly elevated amount of these metals for the VA along the lower slopes of CVL. The low values of $\mathrm{Pb}$ may be attributed to their removal through the crops by plant uptake mechanism. On the contrary, elevated $\mathrm{Cu}$ and $\mathrm{Cd}$ values can be assigned to agricultural activities and waste decomposition accumulation.

The value of $\mathrm{Mn}$ and $\mathrm{Mg}$ were found up to 2,772 $\mathrm{mg} \mathrm{Kg}^{-1}$ and 3,637 $\mathrm{mg} \mathrm{Kg}^{-1}$ in Guangxi and Morroco mining zones, respectively [23,24], which are considerably higher than ours. It is worth noting that our samples are the VA products coming from a volcano eruption and cannot be directly compared to the uncontaminated soils. However, the tentative comparison leads to the conclusion that some of our sampling soils can be contaminated by some elements like $\mathrm{Cd}, \mathrm{Cu}$, and $\mathrm{Cr}$ and deficient for $\mathrm{B}, \mathrm{P}$, and $\mathrm{Zn}$. The contamination can be justified by the elevated amount of the products ejected during the eruption of the volcano and to the industry activities developed in the area. The deficiency can be due to the constant removal of these elements by the plant growth process since these soils are used for agricultural activities. On the one hand, the dominant values of $\mathrm{Si}, \mathrm{Fe}$, and $\mathrm{Al}$ lead 


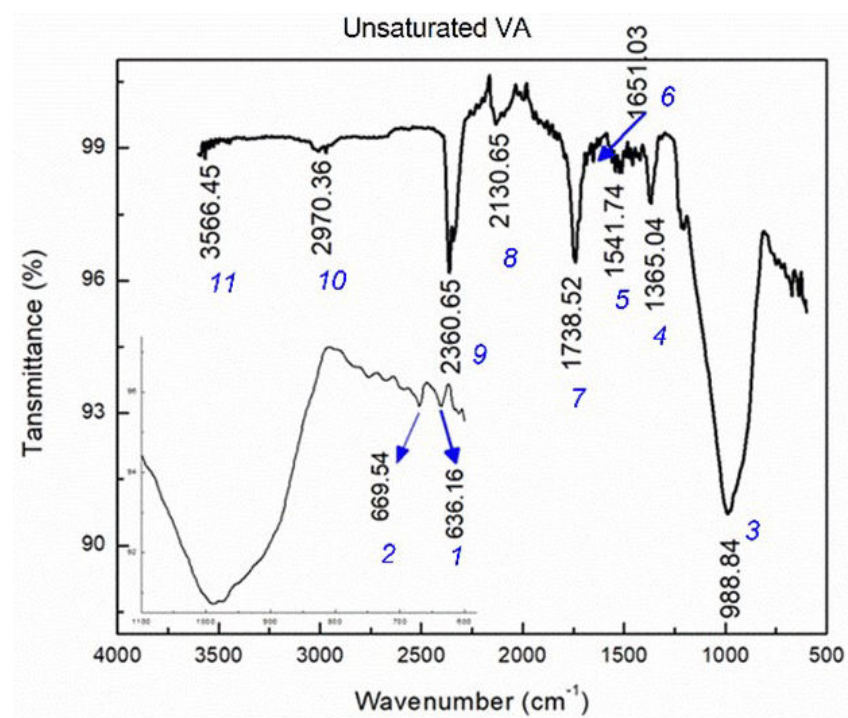

a)

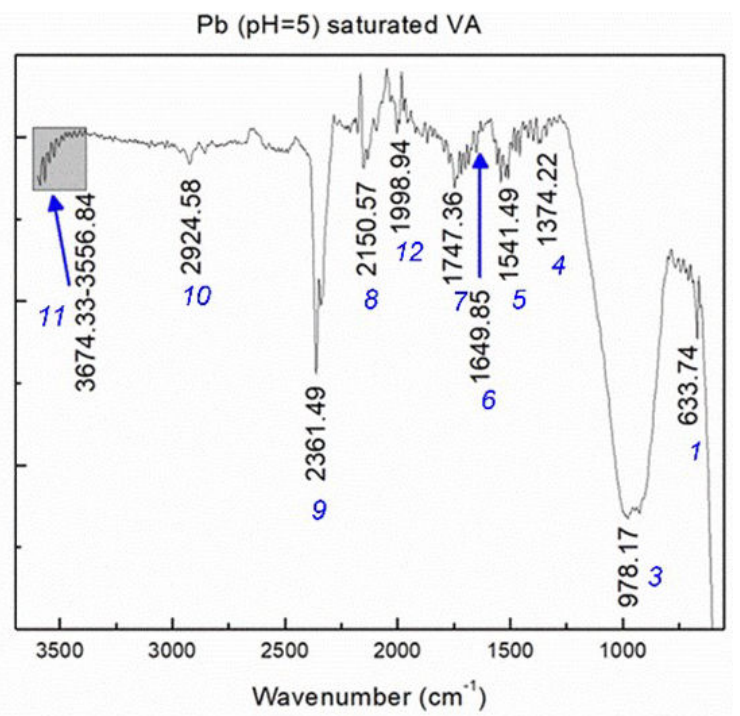

b)

FIGURE 2. Normalized Fourier Transform InfraRed spectrum of unsaturated VA with the assigned peaks and their corresponding energies in $\mathrm{eV}$, for unsaturated a) and $\mathrm{Pb}$-saturated $\mathrm{VA} \mathrm{b}$ ). The insert is shown to highlight the weak peaks in the high region.

to their use in the construction area for manufacturing cement, Al, and Fe products. The samples can be used as adsorbents to remove pollutants such as $\mathrm{Pb}, \mathrm{Cr}$, etc.

According to the US EPA international method [16], the leaching tests performed with deionized water and measured by ICP-OES showed that our VA samples have the potentiality to adsorb $\mathrm{Al}, \mathrm{B}, \mathrm{Li}$, and $\mathrm{S}$. It was observed a nonsignificant release of $\mathrm{Ca}, \mathrm{K}, \mathrm{Mg}, \mathrm{Na}, \mathrm{Ni}$ and $\mathrm{Pb}$ into the water with a difference of about 0.01 to almost 0.5 from $\mathrm{Ca}$ and 0.1 $\mathrm{mg} \mathrm{L}^{-1}$ for $\mathrm{Pb}$ compared with deionized water. The elements $\mathrm{As}, \mathrm{Cu}, \mathrm{P}, \mathrm{Mg}, \mathrm{V}$, and $\mathrm{Zn}$ are not released. The release of such elements can facilitate the retention of metals present in aqueous solutions by ion exchange process. Similar results were found by Botto et al. [5] for VA from Puyehue Cordon Caulle Volcanic Complex (Chile) collected at Villa La Angostura using for the removal of As. These results could be a good signal for the removal process using our studied VA in the natural form.

Infrared spectra of VA samples saturated and unsaturated with $\mathrm{Pb}^{2+}$ (Fig. 2) showed mainly peaks corresponding to the deformation of $\mathrm{M}-\mathrm{OH}$ functional groups $(\mathrm{M}=\mathrm{Mg}, \mathrm{Al}$, $\mathrm{Fe}$ ) or Si-O stretching vibrations $[4,25]$. Also, those corresponding to the $\mathrm{Si}-\mathrm{O} / \mathrm{Al}-\mathrm{O}$ from aluminosilicate framework and/or P-O stretching vibrations from polyphosphates [4,25], $\mathrm{C}-\mathrm{O}$ stretching and bending vibrations from carbonate groups [26]. In general, minimal differences in the transmittance intensity of these peaks were observed, indicating changes in VA during the $\mathrm{Pb}^{2+}$ adsorption process; however, characterization of the saturated and unsaturated materials by other techniques is necessary to establish the mechanism by which $\mathrm{Pb}^{2+}$ is adsorbed on these materials.

\subsection{Adsorption capacity of VA to remove lead in aque- ous solution}

The adsorption capacity of VA for the removal of $\mathrm{Pb}^{2+}$ at the solution $\mathrm{pH} \mathrm{3,} \mathrm{4,} \mathrm{and} 5$ are shown in Fig. 3 for the three samples P1, P2, and P3. The maximum adsorption capacity (7.59 $\left.\mathrm{mg} \mathrm{g}^{-1}\right)$ is obtained from $\mathrm{P} 1$ at $\mathrm{pH} 5$, whereas the minimum (1.49 $\mathrm{mg} \mathrm{g}^{-1}$ at $\mathrm{pH} 4$ ) is from P2. It is observed that in $\mathrm{P} 1$, the adsorption capacity increases with the increase of $\mathrm{pH}$, while in P2 and P3, a slight decrease is observed from $\mathrm{pH} 3$ to 4 . However, the increase is noticed at $\mathrm{pH} 5$.

The comparison was elsewhere made based on the selection scale of low (e.g., $10 \mathrm{mg} \mathrm{L}^{-1}$ ) and high (e.g., $200 \mathrm{mg}$ $\mathrm{L}^{-1}$ ) residual concentration. For that purpose, the adsorption capacity of $\mathrm{VA}$ for $\mathrm{Pb}^{2+}$ from $\mathrm{P} 2$ and $\mathrm{P} 3$ at all $\mathrm{pH}$ are in good agreement with results $\left(\sim 1.5-4.75 \mathrm{mg} \mathrm{g}^{-1}\right)$ of Ref. [10]

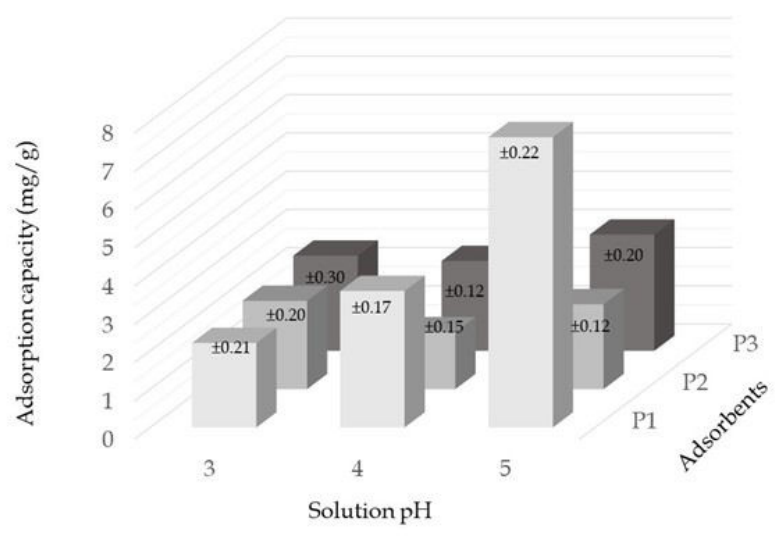

FIGURE 3. Trend of VA adsorption capacity $\left(\mathrm{mg} \mathrm{g}^{-1}\right)$ for the removal of $\mathrm{Pb}^{2+}$ in aqueous solution. The experiments were performed in triplicate, and the average value of the adsorption capacity and the standard deviation value is shown. 
obtained at $\mathrm{pH} 4.9$ with smectite material as an adsorbent in the $\mathrm{Pb}$ (II) concentration range of $50-130 \mathrm{mg}^{-1}$. As well, the comparison can also be made with some biomass of marine algae like cadium taylori from Australia $\left(9 \mathrm{mg} \mathrm{g}^{-1}\right)$ and padina gymnospora from Rio de Janeiro $\left(4.3 \mathrm{mg} \mathrm{g}^{-1}\right)$ given in Ref. [27]. More to that, the maximum adsorption capacity can be compared with that $\left(6.8 \mathrm{mg} \mathrm{g}^{-1}\right)$ obtained on kaolinite material at $\mathrm{pH} 5$ but at the concentration of $2,000 \mathrm{mg}$ $\mathrm{L}^{-1}$ [28]. On the other hand, our results are low compared to those reported on Jordanian Kaolinite and Tunisian Smectite, respectively, by Al-Harahsheh et al. [29] and Eloussaief et al. [30]. They respectively reported the adsorption capacity of $13.32 \mathrm{mg} \mathrm{g}^{-1}$ at $\mathrm{pH} 5$ with the concentration of $131.32 \mathrm{mg}$ $\mathrm{L}^{-1}$ and $75.35 \mathrm{mg} \mathrm{g}^{-1}$ at $\mathrm{pH} 5.5-6.5$ with $25-275 \mathrm{mg} \mathrm{L}^{-1}$ of concentration range. On the contrary, the results of Dawodu et al. [31] obtained on Agbani clay in the concentration range of $20-100 \mathrm{mg} \mathrm{L}^{-1}$ at $\mathrm{pH} 6$ are too low $\left(\sim 0.2-0.82 \mathrm{mg} \mathrm{g}^{-1}\right)$ compared to ours.

The knowledge of the surface charge is necessary for the understanding of the adsorption process onto the VA material. For these reasons, the zero point of charge pHZPC was determined by titration method according to [32]. The pHZPC of $\mathrm{P} 1, \mathrm{P} 2$, and $\mathrm{P} 3$ was $7.64,7.57$, and 7.25, respectively, almost neutral. It is known that the surface of the adsorbent sample is positively charged below pHZPC, suggesting that the adsorbent surface favors the electrostatic attraction with anions $[12,32]$. The surface is neutral at pHZPC. The re- sults show that $\mathrm{Pb}^{2+}$ cations were better removed at $\mathrm{pH} 5<$ pHZPC, with an adsorption capacity of $7.60 \mathrm{mg} \mathrm{g}^{-1}$. Knowing that the electrostatic attraction with anions is predominant in that range, one can attribute the adsorption process to the ion exchange mechanism in which $\mathrm{Pb}^{2+}$ was exchanged with another cation (maybe $\mathrm{Ca}^{2+}$ or $\mathrm{Mg}^{2+}$, etc.) on the surface. Leaching tests showed that these elements are little released and can contribute to the adsorption process. The surface of P1 has a higher pHZPC than that of P2 following P3. These preliminary adsorption results certify that our VA soils in the natural form can be used as adsorbents for pollutants removal.

The value of $1,028.11 \mathrm{mg} \mathrm{Kg}^{-1}$ was obtained from ICP-OES analysis for $\mathrm{Pb}$ concentration onto unsaturated $\mathrm{P} 1$. Since sample P1 has a high adsorption capacity, it was chosen for further experiments (XANES). This concentration is considerably increased in $\mathrm{Pb}$-saturated samples. This result also suggests a slight change in the chemical composition for the adsorbed samples.

\subsection{XANES results}

Figure 4a) presents the normalized XANES absorption spectrum at $\mathrm{Pb} \mathrm{L} 3$ edge of $\mathrm{Pb}-\mathrm{SVA}-\mathrm{P} 1$ compared to the spectra of some selected reference compounds ordered by their $\mathrm{E}_{0}$ energy shift determined as the maximum of the first derivative. The experimental energy edge of Pb-SVA-P1 is at 13,035.82 $\mathrm{eV}$ which is a little higher value than the theoretical $\mathrm{Pb} \mathrm{L} 3$
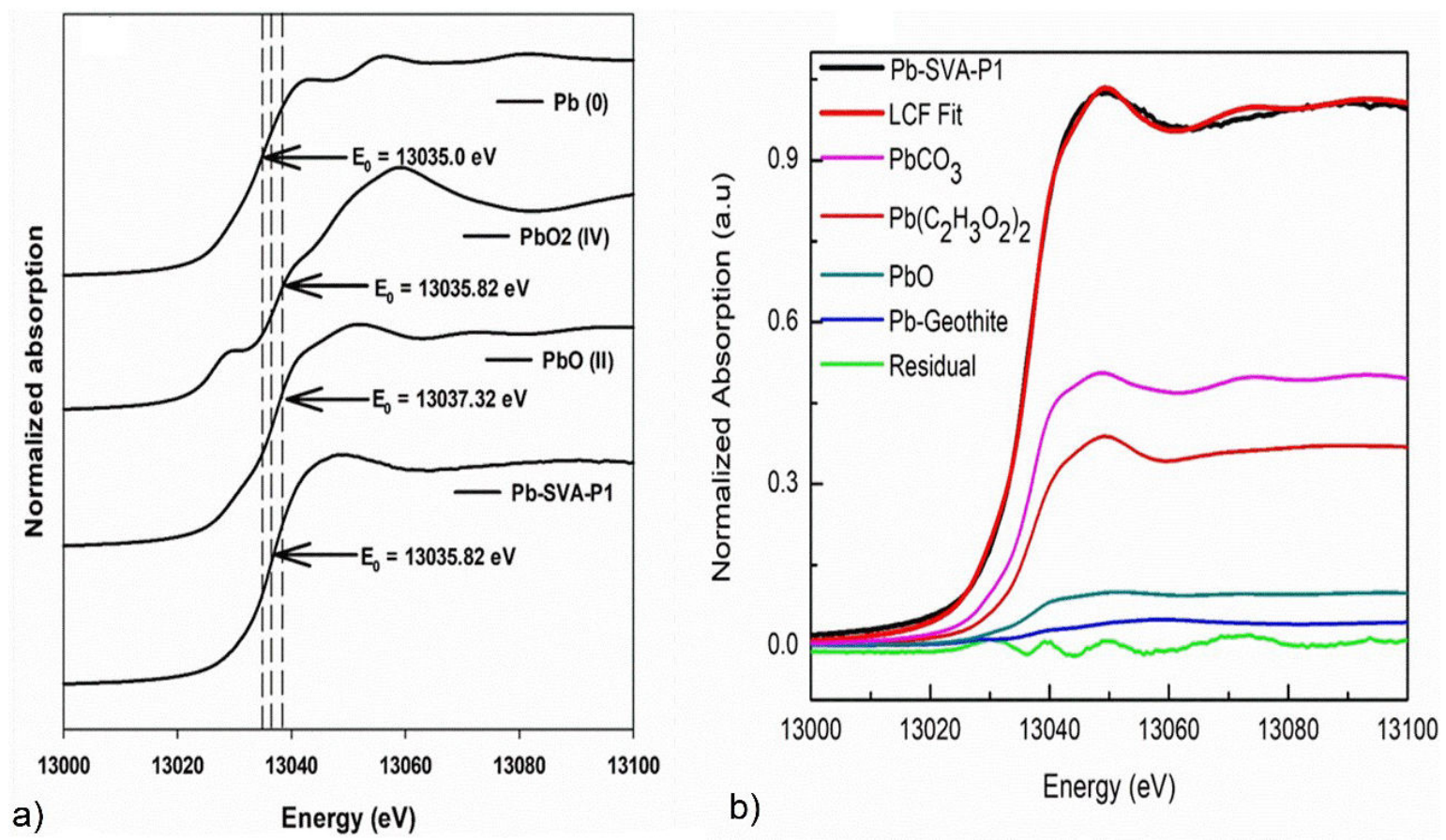

FIGURE 4. a) Pb XANES spectra of Pb-SVA-P1 and reference compounds: Lead metal (Pb; (0)), Lead monoxide (PbO; (II)), and lead dioxide $\left(\mathrm{PbO}\right.$; (IV)). Dotted lines show the $\mathrm{E}_{0}$ of model compounds. The number in parenthesis indicates the oxidation states. b) Linear combination analysis of $\mathrm{Pb}$ L3 XANES spectra of sample Pb-SVA-P1 using reference compounds: lead monoxide $(\mathrm{PbO}), \mathrm{Pb}$ acetate $\left(\mathrm{Pb}\left(\mathrm{C}_{2} \mathrm{H}_{3} \mathrm{O}_{2}\right)_{2}\right)$, $\mathrm{Pb}$ carbonate or cerussite $(\mathrm{PbCO} 3)$, and $\mathrm{Pb}$-goethite $(\mathrm{Pb}-\alpha-\mathrm{FeOOH})$. The residual expresses the difference between the experimental and theoretical curves obtained after fitting. R-factor is 0.0009 and $\triangle \mathrm{E}_{0}$ is $-0.509 \mathrm{eV}$. 
edge energy $(13,035 \mathrm{eV})$. $\mathrm{Pb}$ saturated VA reaches its edge energy after metal, at the same level of $\mathrm{PbO}$ and just before $\mathrm{PbO}_{2}$ suggesting an oxidation state of +2 . According to these observations, it is concluded that the oxidation state of lead used for adsorption experiments (that was +2 ) is kept constant, and the Pb-SVA-P1 may content lead species in oxidation state (II).

The normalized spectrum of Pb-SVA-P1 is similar to that of $\mathrm{PbO}$, suggesting that $\mathrm{Pb}$ (II) in the volcanic ash has the same geometry as $\mathrm{PbO}$ in which $\mathrm{Pb}$ (II) is in a pyramidal coordination. The XANES study of cement also showed that $\mathrm{Pb}$ (II) in the cement samples is mainly in a pyramidal coordination [33]. This can be compared with the volcanic ash materials, which have been proven to be efficient in cement production in the construction sector [3,4]. It is known that $\mathrm{XAS}$ at the $\mathrm{Pb}-\mathrm{L} 3$ edge is assimilated to an electronic transition from the $2 p$ core electron to an unoccupied orbital. Because of the dipole selection rule, normally, all electronic transitions are not allowed between the $2 p$ level to unoccupied orbitals. Nevertheless, the characteristic of the main peak in the derivative spectrum of Pb-SVA-P1 suggests possible electronic transitions between $2 p \rightarrow 6 d$ and/or $2 p \rightarrow 6 s$ unoccupied orbitals. However, in $\mathrm{C} 4 \mathrm{v}$ symmetry in a pyramidal geometry, the hybridization between the $\mathrm{Pb}$ (II) $6 \mathrm{~s}$ and $6 \mathrm{p}$ orbitals can create vacancies in the $5_{a 1}$ level allowing the $2 p \rightarrow 6 s$ transition as described in Refs. [33,34]. Since the quadrupole $2 \mathrm{p}-6 \mathrm{~d}$ transition occurs with a low probability while the dipolar $2 p-6 s$ occurs with a high probability, one can propose that in the investigated VA materials, the electronic transitions occurring could be assimilated to $2 p \rightarrow 6 s$.

A PCA was applied to determine the suitable standards likely to be present in VA and useful to perform LCF analysis. The lead compounds $\mathrm{PbS}, \mathrm{PbO}, \mathrm{PbO}_{2}, \mathrm{~Pb}_{2} \mathrm{O}_{4}, \mathrm{~Pb}\left(\mathrm{CO}_{3}\right)$, $\mathrm{Pb}\left(\mathrm{SO}_{4}\right), \mathrm{Pb}\left(\mathrm{C}_{2} \mathrm{H}_{3} \mathrm{O}_{2}\right)_{2}$, and $\mathrm{Pb}$-Goethite $(\mathrm{Pb}-\alpha-\mathrm{FeOOH})$ were used as standards for that purpose. The choice of these standards was guided by the literature reviews concerning the composition of VA $[4,35,36]$. The PCA analysis was first performed to check the standards likely to be present in the sample. According to the literature, those that are not likely to be present in the VA samples and the PCA check results were discarded. The next step was performed using all standards potentially likely to be present. The results suggested that the main components of $\mathrm{VA}$ are $\mathrm{Pb}$ carbonate, $\mathrm{Pb}$ acetate, and $\mathrm{Pb}$ oxide $\mathrm{II}$ in addition to $\mathrm{Pb}$ - goethite.

An LCF shown in Fig. 4b) was performed on sample $\mathrm{Pb}-\mathrm{SVA}-\mathrm{P} 1$ using a set of four reference compounds proposed by PCA, representing: Lead associated to organic matter $\left(\mathrm{Pb}\left(\mathrm{C}_{2} \mathrm{H}_{3} \mathrm{O}_{2}\right)_{2}\right)$, lead associated to carbonate or cerussite $\left(\mathrm{PbCO}_{3}\right)$, lead monoxide $(\mathrm{PbO})$ and lead associated to iron oxyhydroxides (Pb-goethite, $\mathrm{Pb}-\alpha-\mathrm{FeOOH})$. The use of goethite was to check a possible interaction between hydroxyl and lead. The residual curve is as good minimized, suggesting that the analysis of the $\mathrm{Pb}$ XANES signature may be explained principally by the contribution of $\mathrm{Pb}$ associated with: carbonate $(44.4 \%)>$ organic matter $(34.5 \%)>$ monoxide $(14.7 \%)>$ iron oxyhydroxides $(6.4 \%)$. This suggests that a certain amount of minor $\mathrm{Pb}$ species may be present in the studied samples at a negligible percentage.

The major components are cerussite and $\mathrm{Pb}$-organic matter due to the $\mathrm{C}-\mathrm{O}$ or $\mathrm{O}-\mathrm{H}$ functional groups related to $\mathrm{CO}_{2}$ and/or to water molecules formed during VA weathering and adsorption. Additionally, Somasundaram et al. [35] also revealed the high concentration of carbonate and organic matter bound-Pb in soil samples, and Denys et al. [36] showed that the occurrence of cerussite in soils strongly control the $\mathrm{Pb}$-bioaccessibility.

These results show that there is an interaction of the sorbed element $(\mathrm{Pb})$ with some groups (probably related to hydroxyl or water molecules) of the surface of the VA samples. The presence of cerussite, $\mathrm{Pb}$ acetate, and $\mathrm{Pb}$ monoxide can be explained by both micro precipitation and adsorption over the groups of the materials. Since the LCF showed a significant contribution of cerussite, lead acetate, and lead monoxide, we can propose microprecipitation and ion exchange as the main mechanism. As the VA surface is repelling cation, the possibility for another $\mathrm{Pb}$ to be coordinated or interact with the sorbed $\mathrm{Pb}$ is to replace one of the exchangeable cations (like $\mathrm{Ca}^{2+}, \mathrm{K}^{+}, \mathrm{Na}^{+}, \mathrm{Mg}^{2+}$ ), or probably a part of the aggregates of $\mathrm{PbO}$ over the particles. In addition, leaching tests performed by ICP-OES have shown that about $12.65 \%$ of alkali elements $\left(\mathrm{Na}^{+}, \mathrm{K}^{+}\right)$and $90 \%$ of alkaline $\left(\mathrm{Ca}^{2+}, \mathrm{Mg}^{2+}\right)$ were released in VA. This might suggest a possibility of ion exchange as one of the adsorption mechanisms for $\mathrm{Pb}$ sorbed onto VA [37].

\section{Conclusions}

The present study shows that the VA from the CVL of Mount Cameroon volcano can also be used as an economically sustainable adsorbent for removing pollutants from contaminated water. Furthermore, XANES results confirm that the $\mathrm{Pb}$-adsorbed from the solution in the presence of $\mathrm{VA}$ is in the oxidation state +2 and that Pb-SVA-P1 is mainly composed of lead associated with carbonate, acetate, monoxide, and goethite. The results showed that the lead removal occurred mainly by microprecipitation of lead acetate and carbonate (cerussite) and a possible ion-exchange forming lead monoxide. It is herein proven that XANES can depict the adsorption mechanism and determine the chemical components present in an unknown sample. It thus might appear as a powerful characterization tool for adsorbent materials containing heavy elements.

\section{Funding}

TWAS; CONACYT CB-286990-2016; CONACYT PN3947-2016.

\section{Acknowledgments}

B. Thiodjio Sendja is grateful to the TWAS fellowship program carried out in Mexico. 


\section{Conflicts of Interest}

The authors declare that there is no conflict of interest.

1. G. Cai, T. Noguchi, H. Degée, J. Zhao, R. Kitagaki, Volcanorelated materials in concretes: a comprehensive review, Environ. Sci. Pollut. Res. 23 (2016) 7220, htts://doi.org/ $10.1007 / \mathrm{s} 11356-016-6161-\mathrm{z}$

2. V.E. Manga, C.M. Agyingi, C.E. Suh, Trace Element Soil Quality Status of Mt. Cameroon Soils, Adv. Geol. 2014 (2014) 894103, htts://doi.org/10.1155/2014/894103.

3. H.K. Tchakouté, S. Kong, J.N.Y. Djobo, L.N. Tchadjié, D. Njopwouo, A comparative study of two methods to produce geopolymer composites from volcanic scoria and the role of structural water contained in the volcanic scoria on its reactivity, Ceram. Int. 41 (2015) 12568. htts://doi.org/10. $1016 / j . c e r a m i n t .2015 .06 .073$

4. J. N. Y. Djobo, A. Elimbi, H.K. Tchakouté, and S. Kumar, Reactivity of volcanic ash in alkaline medium, microstructural and strength characteristics of resulting geopolymers under different synthesis conditions, J. Mater. Sci. 51 (2016) 10301. htts://doi.org/10.1007/s10853-016-0257-1

5. I.L. Botto, M.E. Canafoglia, D. Gazzoli, M.J. González, Spectroscopic and Microscopic Characterization of Volcanic Ash from Puyehue-(Chile) Eruption: Preliminary Approach for the Application in the Arsenic Removal, J. Spectrosc. 2013 (2013) 254517, htts://doi.org/10.1155/2013/254517.

6. N. Jaafarzadeh, H. Amiri, M. Ahmadi, Factorial experimental design application in modification of volcanic ash as a natural adsorbent with Fenton process for arsenic removal, Environ. Technol. 33 (2012) 159. htts : / / doi.org/10.1080/ 09593330.2011 .554887

7. A. Esmaili, S. Nasseri, A.H. Mahvi, R. Atash-Dehghan, Adsorption of lead and zinc ions from aqueous solutions by volcanic ash soil (VAS), Proceedings of the 8th international conference on Environmental Science and Technology (2003) pp. 8-10.

8. F. B. Júnior, M. Farina, S. Viegas, and W.D.G Kempinas, Toxicology of metals and metalloids, Bio. Med. Res. Int. ID 2014 (2014) 253738, htts://doi.org/10.1155/ $2014 / 253738$

9. G. Chen and L. Shi, Removal of $\mathrm{Cd}(\mathrm{II})$ and $\mathrm{Pb}(\mathrm{II})$ ions from natural water using a low-cost synthetic mineral: behavior and mechanisms, RSC Adv. 7 (2017) 43445, htts : / / doi .org/ $10.1039 / \mathrm{C} 7 \mathrm{RA} 08018 \mathrm{~B}$

10. J.K. Mbadcam, S.G. Anagho, J. Ndi-nsami, and A.M. Kammegne, Kinetic and equilibrium studies of the adsorption of lead (II) ions from aqueous solution onto two Cameroon clays: kaolinite and smectite, J. Environ. Chem. Ecotoxicol 3 (2011) 290. https://doi.org/10.5897/JECE. 9000038

11. WHO, International standards for drinking-water, 3rd ed. (World Health Organization, Geneva, 1974). htts: //apps. who.int/iris/handle/10665/39989
12. J. Li et al., Sorption mechanisms of lead on silicon-rich biochar in aqueous solution: Spectroscopic investigation, Sci. Total Environ. 672 (2019) 572, htts : / doi.org/10.1016/j. scitotenv.2019.04.003.

13. A. Funatsuki, M.Takaoka, K. Oshita, and N. Takeda, Methods of Determining Lead Speciation in Fly Ash by X-ray Absorption Fine-Structure Spectroscopy and a Sequential Extraction Procedure, Anal. Sci., 28 (2012) 481, htts://doi.org/ 10.2116/analsci.28.481

14. N.A. Medellin-Castillo et al., Removal of fluoride from aqueous solution using acid and thermally treated bone char, Adsorption 22 (2016) 951. htts://doi.org/10.1007/ s10450-016-9802-0

15. F. Castillo, M. Avalos-Borja, H. Jamieson, H., G. HernándezBárcenas, N. Martínez-Villegas, Identification of diagenetic calcium arsenates using synchrotron-based micro X-ray diffraction, B. Soc. Geol. Mex. 67 (2015) 479, https://www. jstor.org/stable/24921505.

16. EPA, U.S., Method EPA1311: Toxicity Characteristic Leaching Procedure (TCLP), Agency EP, editor (Washington DC, USA, 1992).

17. A. Di Cicco et al., Novel XAFS capabilities at ELETTRA synchrotron light source. J. Phys.: Conf. Ser., 190 (2009) 012043, https://doi.org/10.1088/1742-6596/ $190 / 1 / 012043$

18. B. Ravel, M. Newville, ATHENA, ARTEMIS, HEPHAESTUS: data analysis for X-ray absorption spectroscopy using IFEFFIT, J. Synchrotron Rad. 12 (2005) 537, htts: //doi.org/10. $1107 / \mathrm{S} 0909049505012719$

19. V.B. Che et al., Evaluating the degree of weathering in landslide-prone soils in the humid tropics: the case of Limbe, S W Cameroon, Geoderma 170 (2012) 378, htts://doi. org/10.1016/j.geoderma.2011.10.013

20. G.-L. Zhang, J.-H. Pan, C.-M. Huang, Z.-T. Gong, Geochemical features of a soil chronosequence developed on basalt in Hainan Island, China, Rev. Mex. Cienc. Geol. 24 (2007) 261, https://www.scielo.org. $\mathrm{mx} / \mathrm{scielo}$.php?script $=$ sciarttext \&pid= S1026-87742007000200012\&lng=es\&nrm=iso

21. B.A. Fonge, E.N. Nkoleka, F.Z. Asong, S.A. Ajonina, and V.B. Che, Heavy metal contamination in soils from a municipal landfill, surrounded by banana plantation in the eastern flank of Mount Cameroon, Afr. J. Biotechnol. 16 (2017) 1391. htts://doi.org/10.5897/AJB2016.15777

22. C. D. Jadia and M. H. Fulekar, Phytotoxicity and remediation of heavy metals by fibrous root grass (sorghum), J. Appl. Biosci, 10 (2008) 491.

23. O. El Hamiani et al., Toxicity assessment of garden soils in the vicinity of mining areas in Southern Morocco, J. Hazard. Mater., 177 (2010) 755, htts://doi.org/10.1016/j. jhazmat.2009.12.096 
24. D. Li et al., Mineralogy of the No. 6 Coal from the Qinglong Coalfield, Guizhou Province, China, Energ. Explor. Exploit., 26 (2008) 347, htts://doi.org/10.1260/ 014459808788262279

25. N.V. Chukanov, A.D. Chervonnyi, Infrared spectroscopy of minerals and related compounds, (SpringerMineralogy, 2016), htts://doi.org/10.1007/978-3-319-25349-7.

26. S. Petit, J.L. Robert, A. Decarreau, G. Besson, O. Graudy, F. Martin, Apport des méthodes spectroscopiques á la caractérisation des phyllosilicates 2/1, Bull. Centre Rech. Expl. Prod. Elf Aquitaine, 19 (1995) 119.

27. Z.R. Holan, and B. Volesky, Biosorption of lead and nickel by biomass of marine algae, Biotechnol. Bioeng., 43 (1994) 1001, htts://doi.org/10.1002/bit.260431102

28. S. Shahmohammadi-Kalalagh, H. A. H. Nazemi, and M. Manshouri, Isotherm and kinetic studies on adsorption of $\mathrm{Pb}, \mathrm{Zn}$ and $\mathrm{Cu}$ by kaolinite, Caspian J. Environ. Sci. 9 (2011) 243, https://research.guilan.ac.ir/cjes

29. M. Al-Harahsheh, R. Shawabkeh, A. Al-Harahsheh, K. Tarawneh, and M.M. Batiha, Surface modification and characterization of Jordanian kaolinite: application for lead removal from aqueous solutions, Appl. Surf. Sci., 255 (2009) 8098. htts://doi.org/10.1016/j.apsusc.2009. 05.024

30. M. Eloussaief, W. Hamza, N. Kallel, and M. Benzina, Wastewaters decontamination: mechanisms of $\mathrm{Pb}(\mathrm{II}), \mathrm{Zn}(\mathrm{II})$, and $\mathrm{Cd}(\mathrm{II})$ competitive adsorption on tunisian smectite in single and multisolute systems, Environ. Prog. Sustain., 32 (2013) 229, htts : //doi.org/10.1002/ep.11609

31. F.A Dawodu, G.K. Akpomie, P.C.N. Ejikeme, Equilibrium, thermodynamic and kinetic studies on the adsorption of lead(II) from solution by “Agbani Clay", Res. J. Eng. Sci. 1 (2012) 9.

32. N.A. Medellin-Castillo et al., Adsorption of Fluoride from Water Solution on Bone Char, Ind. Eng. Chem. Res., 46 (2007) 9205. htts://doi.org/10.1021/ie070023n

33. J. Rose et al., X-ray Absorption Spectroscopy Study of Immobilization Processes for Heavy Metals in Calcium Silicate Hydrates: 1. Case of Lead, Langmuir 16 (2000) 9900, htts : //doi.org/10.1021/la0005208

34. X. Behrens, 8th International Conference on X-ray Absorption Spectroscopy, (Berlin 1994).

35. J. Somasundaram, R. Krishnasamy, S. Mahimairaja, and P. Savithri, Dynamics of lead $(\mathrm{Pb})$ in different soil conditions, $J$. Environ. Sci. Eng., 48 (2006) 123.

36. S. Denys, J. Caboche, K. Tack, P. Delalain, Bioaccessibility of lead in high carbonate soils, J. Environ. Sci. Health, Part A, 42 (2007) 1331, htts://doi.org/10.1080/ 10934520701435569

37. X. Yang, G. Xu, H. Yu, Removal of lead from aqueous solutions by ferric activated sludge-based adsorbent derived from biological sludge, Arabian J. Chem. 12 (2019) 4142, htts : //doi.org/10.1016/j.arabjc.2016.04.017 